\title{
Monitoring Pollution of the Tigris River in Baghdad by Studying Physico-Chemical Characteristics
}

Montazer K. Mensoor ( $\nabla$ montazerkamel@gmail.com )

International Center for Training, Research \& Development (ICTRD) https://orcid.org/0000-0002-7415$864 \mathrm{X}$

\section{Research Article}

Keywords: Pollution, physico-chemical characteristics, Tigris River, Baghdad

Posted Date: November 12th, 2021

DOI: https://doi.org/10.21203/rs.3.rs-1074093/v1

License: (9) This work is licensed under a Creative Commons Attribution 4.0 International License. Read Full License 


\section{Abstract}

The current study aimed at exploring and identifying pollution indicators of the Tigris River in Baghdad through studying physical and chemical characteristics. Monthly water samples were collected from four locations along the Tigris River in Baghdad for 12 months period. The studied characteristics of the current study included surface water temperature, $\mathrm{pH}$, turbidity, salinity, electrical conductivity, total suspended solids, total dissolved solids, total hardness, dissolved oxygen, biochemical oxygen demand, chemical oxygen demand, phosphate, nitrate, and Sulphate. The results showed that the mean values of all the studied physical and chemical characteristics except $\mathrm{pH}$, temperature, and phosphate were higher than the acceptable limits of the Iraqi river water guidelines and international standards. The current study concluded that the Tigris River water was heavily polluted from untreated sewage discharge and other industrial, agricultural, and domestic activities. The study recommended immediate measures to be taken to end the nonstop inflow of sewage and wastes into the Tigris River water from the residential, commercial, and institutional activities in Baghdad.

\section{Introduction}

Pollution levels in the Tigris River in Iraq are on the increase. The river pollution has a serious negative effect on humans, animals, and the way of life. Consequences of such pollution has led to the bioaccumulation of heavy metals in freshwater fishes (Mensoor and Said, 2018; Balasim, 2012), increase of heavy metals in river water (Al-Obaidy, Al-Janabi, and Al-Kubaisi, 2014), hugh levels of heavy metals in river water sediments (Balasim, 2012; Al-Obaidy, Al-Janabi, and Al-Mashhady, 2016), increased river water

turbidity (Al-Abdrabba et al, 2015), rise in total salinity (Rahi and Halihan, 2018), increased levels of total hardness (Dabdoob and Ibrahim, 2012), high concentrations of BOD and COD (Ismail and Abed, 2013; AlHiyali, Ma'alah, and Al-Azzawi, 2016), and contamination of river water with microbiological pathogens (Abd Al-Kareem, Al-Arajy, and Jassim, 2015; Al-Bayatti, Al-Arajy, and Al-Nuaemy, 2012).

Physical characteristics such as water temperature, turbidity, and total hardness of the river water can be good indicators for determining pollution. Similarly, chemical characteristics (electrical conductivity, $\mathrm{pH}$, concentrations of $\mathrm{K}^{+}, \mathrm{Na}^{+}, \mathrm{Cl}$, and $\mathrm{NO}^{3}$ etc.) represent key parameters in monitoring and identifying pollution in river water (Chapman, 2003). Microbiological contamination is also an important factor with regard to the treatment requirements and safe recycle of effluents of river waters (Basílico, de Cabo, and Faggi, 2015).

Most of the domestic and industrial wastes are discharged directly into the Tigris River in Baghdad without any sufficient waste management, which makes the Tigris River water severely polluted specially with organic substances. Quality of the Tigris river water in Baghdad was classified as "very poor" (Khudair, 2013). A more recent study classified the Tigris River as "fair quality" (Ibrahim, Abd Ali, and Hussein, 2018). With the upsurge of industrial activities and the increased anthropogenic processes due to the rise of population in Baghdad, the Tigris River would be more exposed to pollution with effluents 
and wastes. In the end, this would lead to a serious public health problem in addition to the severe consequences on the environment.

The Tigris River is the only source for potable water supplies, fish consumption and farming, agricultural water supply, and also used for navigation, recreation, and industries in Baghdad. Hence, and according to the recommendations of the World Health Organization (WHO, 2002), it's very important to keep monitoring and evaluating the river water quality by conducting frequent ecological, biological, and physico-chemical assessments and examination of water supplies. This would involve monitoring at all times, from a public health perspective, over safety and sustainability of water supplies (Okorafor et al, 2012).

The aim of the current study is to monitor pollution of the Tigris River through exploring and identifying some physical and chemical characteristics of the Tigris river water within the city of Baghdad.

Monitoring and evaluating physico-chemical characteristics in the river water will help identify the impact of pollutants on the water quality of the Tigris River. Consequently, a better intervention and solution by the relevant authorities would be taken to help mitigate the problem of Tigris River pollution in Iraq.

\section{Materials And Methods:}

\subsection{Study Area:}

Four sampling locations were selected for the current study. Al-Rashdiya area was the labeled as sampling station. This area is located northern of Baghdad and it marks the entrance of the Tigris River to the city of Baghdad. It is located at the following GPS coordinates (Latitude $33^{\circ} 25^{\prime} 42.0^{\prime \prime} \mathrm{N}$ and Longitude $\left.44^{\circ} 20^{\prime} 47.7^{\prime \prime} \mathrm{E}\right)$. Bab Al-Muwadam labeled as sampling station 2 and it is located at the following GPS coordinates (Latitude $33^{\circ} 20^{\prime} 37^{\prime \prime} \mathrm{N}$ and longitude $44^{\circ} 22^{\prime} 48^{\prime \prime} \mathrm{E}$ ) in central Baghdad and the third sampling location was the industrial area at Al-Zafaraniya labeled as sampling station 3 and it is located at the following GPS coordinates (latitude $33^{\circ} 17^{\prime} 22.7^{\prime \prime} \mathrm{N}$ and Longitude $44^{\circ} 27^{\prime} 01.8^{\prime \prime} \mathrm{E}$ ) in the south of Baghdad. The last sampling station was the part of the Tigris River where it merges with the Diyala River southern Baghdad and it is located at the following GPS coordinates (Latitude $33^{\circ} 13^{\prime} 15.9^{\prime \prime} \mathrm{N}$ and Longitude $\left.44^{\circ} 30^{\prime} 20.9^{\prime \prime} \mathrm{E}\right)$. Reasons for selecting those four locations come from the recent and previous official reports and academic studies showing the increase of pollution in these areas (Mensoor and Said, 2018; Al-Obaidy, Al-Janabi, \& Shakir, 2015; Ishnawa, Fari, and Sadeq, 2009). Station 2 and 3 were common locations for discharging domestic wastes, effluents from medical and industrial compounds located nearby in addition to the release of municipal wastes. While station 1 and 4 were selected as they represent upstream and downstream of sewage disposal sites. This way, the four selected sampling stations can provide better information and data about the river quality.

\subsection{Collection of Samples:}

Surface water samples from the Tigris River were randomly collected from two different sites for each of the four selected sampling locations. Each sample was labeled with the date of collection and the site of 
sampling. Collection of the samples was done through wading the surface river water at both sampling stations. The river water samples were collected in clean and sterile polyethylene bottles every month during the study period from December 2018 to November 2019. 24 water samples for each site were taken (96 samples in total). The samples were taken immediately after collection from the locations to the laboratory for analysis of physical-chemical parameters.

\subsection{Physical and chemical characteristics:}

The temperature of the water was measured at the sampling locations with a handheld portable thermometer (The Waterproof Thermistor Thermometer - HI93510, U.S.A). A pH meter (HI98108 pHep, U.S.A) was used and it was measured on site. For electrical conductivity (EC), a handheld portable meter (Multi-range EC Meter- HI8733, U.S.A) was used and the test was conducted on site. The total dissolved solids (TDS) and salinity were both measured using a bench-top meter (edge ${ }^{\circledR}$ Multiparameter EC/TDS/Salinity Meter-HI2030-01, U.S.A) and the results of TDS and TSS were expressed in mg $\backslash$ L. The total hardness $(\mathrm{TH})$ was measured using (Water \& Wastewater Multiparameter (with COD) Photometer and $\mathrm{pH}$ meter-HI83399-01, U.S.A) and the results were expressed in $\mathrm{mg} / \mathrm{L}$. The dissolved oxygen (DO) was measured by a bench-top dissolve oxygen meter (HI2400-01, U.S.A) and the results were expressed in $\mathrm{mg} \backslash \mathrm{L}$. Biochemical Oxygen Demand (BOD) was measured by Winkler's method and the results were expressed in mg\L. The Chemical Oxygen Demand (COD) was measured according to the APHA (2017)

method and the results were expressed in $\mathrm{mg} \backslash \mathrm{L}$. Nitrate, phosphate, and sulphate were analyzed by using a bench-top photometer (Multiparameter Benchtop Photometer and pH meter- HI83300-01, U.S.A). All procedures of collecting, preserving, and analyzing the above-mentioned different parameters of water samples were conducted according to the international standard sample collection, preservation, and analysis methods (APHA, 2017; WHO, 2017; Adams, 2017). Statistical analysis was conducted using a Windows-based SPSS (version 23).

\section{Results And Discussion:}

The results of physico-chemical analysis are presented in Table 1. The Tigris River water temperature varied among the 12 months period. But, the values of temperature degrees for the four sampling locations ranged between 11.1 and 30.7. The temperature of the ambient air influenced the variance in water temperature during the 12 months period. The mean values showed that they are within the acceptable range of water temperature of surface river water. Under natural conditions, the temperature of rivers' water varies between $0^{\circ} \mathrm{C}$ and $30^{\circ} \mathrm{C}$ (Chapman, 2003). 
Table 1

Mean values of physico-chemical characteristics of the Tigris River in Baghdad during a period of 12 months

\begin{tabular}{|c|c|c|c|c|c|}
\hline \multirow[t]{2}{*}{ Parameter } & \multirow{2}{*}{$\begin{array}{l}\text { WHO } \\
\text { Standards }\end{array}$} & Station 1 & Station 2 & Station 3 & Station 4 \\
\hline & & Min-Max & Min-Max & Min-Max & Min-Max \\
\hline Temperature ${ }^{\circ} \mathrm{C}$ ) & - & $11.1-30.2$ & $11.6-30.2$ & $11.2-30.2$ & $11.2-30.7$ \\
\hline $\mathrm{pH}$ & $6.5-8.5$ & $7.1-8.2$ & 7.1-8.2 & $7.1-8.2$ & $7.2-8.2$ \\
\hline $\begin{array}{l}\text { EC } \\
\text { (microsemens) }\end{array}$ & 1000 & $\begin{array}{l}620- \\
1210.5\end{array}$ & $589.2-1220$ & $890-1289$ & $934-1295$ \\
\hline TH (mg/L) & $<500$ & $\begin{array}{l}240.3- \\
520.5\end{array}$ & $280.6-530.4$ & $\begin{array}{l}288.6- \\
531.7\end{array}$ & $\begin{array}{l}360.6- \\
546.9\end{array}$ \\
\hline TDS (mg/L) & 500 & $569-804$ & $550.5-804$ & $755-1219$ & $855-1303$ \\
\hline TSS (mg/L) & 25 & $35.5-99.2$ & $40.2-140.8$ & $44.2-141.9$ & $55.6-141.9$ \\
\hline $\mathrm{DO}(\mathrm{mg} / \mathrm{L})$ & 4 & $6.8-8.5$ & $6.9-8.5$ & $6.9-8.5$ & $6.9-8.6$ \\
\hline $\mathrm{BOD}(\mathrm{mg} / \mathrm{L})$ & $<5$ & $3.5-5.9$ & $5.5-6.9$ & $5.5-6.9$ & $5.5-6.9$ \\
\hline $\mathrm{COD}(\mathrm{mg} / \mathrm{L})$ & $20-200$ & $71.3-562.4$ & $70.8-620.5$ & $99.4-612.9$ & $70.1-502.6$ \\
\hline Turbidity(mg/L) & $<5$ & $15.3-30.4$ & $17.5-34.8$ & $17.5-35.6$ & 17.5- 35.6 \\
\hline $\mathrm{No}_{3}(\mathrm{mg} / \mathrm{L})$ & $\leq 10$ & $3.6-11.3$ & $3.2-11.3$ & $6.9-11.4$ & $8.7-11.9$ \\
\hline $\mathrm{SO}_{4}{ }^{2-}(\mathrm{mg} / \mathrm{L})$ & 200 & $130.5-420$ & $\begin{array}{l}209.9-70.50 .13- \\
0.55\end{array}$ & $\begin{array}{l}189.9- \\
470.9\end{array}$ & $\begin{array}{l}188.3- \\
470.8\end{array}$ \\
\hline $\mathrm{PO}_{4}{ }^{3-}(\mathrm{mg} / \mathrm{L})$ & 5.5 & $0.12-0.55$ & & $0.8-0.98$ & $0.41-0.99$ \\
\hline
\end{tabular}

$\mathrm{pH}$ is a key parameter to establish the suitability of river water for different purposes (Venkatesharaju et al, 2010). $\mathrm{pH}$ values ranged between 7.1 to 8.2 for the four stations. These values were also within the permissible WHO standards and these results were similar to previous studies confirming a slight alkalinity of the Tigris River water (Ali, 2018; Al-Abdrabba et al, 2015). This alkalinity of the Tigris River surface water could be attributed to the increased disposal of domestic wastes into the river water at different sites along the Tigris river in Baghdad.

Electrical conductivity (EC) of river water represents a function of the concentration of ions in a solution, the nature of dissolved substance, and the temperature (Tolgyessy, 1993). Results of the current study showed that the values of EC for sampling station 1 ranged between $\left(620-1210.5 \mu \mathrm{S} / \mathrm{cm}^{-1}\right)$ and $(589.2-$ $1220 \mu \mathrm{S} / \mathrm{cm}^{-1}$ ) for sampling station 2. While sampling station 3 had EC values ranging from (890) to (1289) and station 4 had EC values ranging between $\left(934-1295 \mu \mathrm{S} / \mathrm{cm}^{-1}\right)$. Variance of EC values in the Tigris River is correlated with season and river water 
temperature. In winter, lower EC values were detected in all sampling stations. On the other hand, higher EC values were registered during summer and during high temperature season. The reason for the decrease of EC values in winter season is due to the increase of rainfall, which may cause the accumulation of ions in river water. Yearly precipitation in Baghdad ranges from 100 to $400 \mathrm{~mm} /$ year (AlQuraishi, \& Negm, 2019). The increased values in summer could be caused by the increased agricultural, industrial, and other anthropogenic activities at the sampling stations. The results of the current study confirm results obtained by previous studies regarding the increased EC values in the Tigris River water in Baghdad (Flayyh and Rasheed, 2016; Mustafa, 2012). But, the registered values of EC in the current study especially in the fourth station were higher than the results obtained by some more recent studies (Atta, 2020; Al-Ani et al, 2019).

Turbidity generally indicates the quantity of non-dissolved materials and substances in water. Turbidity can be seen as a measure of water clarity and it's usually expressed in Nephelometric Turbidity Unit (NTU) (Berthouex and Brown, 2018). Turbidity values for sampling station 1 ranged between (15.3-30.4 NTU) and (17.5-34.8 NTU) for sampling stations 2. Sampling station 3 and 4 had turbidity values between (17.5-35.6 NTU). These values were significantly higher than the WHO permissible limits of turbidity in freshwaters ( $<5 \mathrm{NTU}$ ). The current results show increased levels of turbidity in the Tigris river water passing through Baghdad and turbidity values registered in this research are higher than the results obtained by previous studies, which indicated the noticeable increase in turbidity in the Tigris River water in Iraq (Alwan, Muhammed, and Jassem, 2013; Al-Suhili, Khudair, and Abdulrazzak, 2016). Reasons for such increased turbidity values in the Tigris River could be attributed to the domestic sewage discharge, industrial wastewater discharge, and agricultural activities at the four sampling stations.

Water hardness is resulted from the presence of calcium (Ca) and magnesium ( $\mathrm{Mg}$ ) compounds, and by different other metals. Hard water does not pose a danger to the public health, but economically it represents one of the most critical water quality parameters (Berthouex and Brown, 2018). In fact, hard water helps teeth and bones grow; and lowers toxicity to lead poisoning from lead pipelines. On the other hand, soft waters are believed to be associated with cardiovascular diseases (Spellman, 2003). The total hardness values of the Tigris River in this study were high. Sampling station 1 showed values ranging between (240.3-520.5) and the values of the sampling station 2 were (280.6-530.4). Sampling station 3 and 4 had total hardness values ranging between (288.6 to 546.9$)$. These values were higher than results obtained by previous studies (Al-Marsoumi, Al-Bayati, Al-Mallah, 2006). The current study indicated that the Tigris River has hard water within the city of Baghdad. This result confirms other previous literature that showed the Tigris River was characterized with high total hardness (Hashim, 2017; Al-Obaidi, 2009). However, the current study showed higher results of water hardness than any other former study.

Values of total dissolved solids (TDS) for sampling station 1 ranged from 569 to $804 \mathrm{mg} \backslash \mathrm{L}$ and for the second sampling station were (550.5-804 mg/L). While sampling station 3 and 4 had values ranging between $(755$ to $1303 \mathrm{mg} / \mathrm{L})$. These values were within the WHO acceptable limits of total dissolved solids in river waters $(1000 \mathrm{mg} \backslash \mathrm{L})$. However, the increased values could be attributed to higher concentrations of discharged effluents nearby the sampling stations since the four sampling locations 
are considered heavily populated and industrialized areas. These results are higher than the results obtained by some previous studies that indicated the Tigris River is characterized with increased values of TDS and that the river water is more saline in the central and southern areas of Iraq (Al-Shujairi, Sulaiman, and Najemaldin, 2015; Ali and Shaban, 2014). Moreover, high concentrations of TDS are common in freshwaters in arid climates, as the case in Iraq, which is considered an arid region (Boyd, 2015). Al-Saady and Abdullah (2014) indicated that the registered increased TDS values along the Tigris river in Baghdad and the southern areas resulted from several factors such as: the agricultural lands along the Tigris river that are characterized with high salt content. In addition, there is a noticeable reduction in levels of the Tigris river water in Baghdad. Moreover, the high evaporation of river water that lead to increasing salt in river water. It's noteworthy that the increase of TDS downstream the Tigris River is resulted from the extensive agricultural activities in the area between Baghdad and Umara city. However, runoff and return flow from agricultural land that contain fertilizers can also lead to high TDS value (Saady and Abdullah, 2014).

Total suspended solids (TSS) represent a measure of the weight of relatively insoluble materials in the ambient water. Suspended solids can include both organic (detritus and biosolids) and inorganic (sand or finer colloids) constituents (Spellman, 2003). The WHO does not have a limit for TSS, but the European Union set $(25 \mathrm{mg} / \mathrm{L}$ ) as a limit for fisheries and aquatic life in rivers (Chapman, 2003). TSS values for the 1 st sampling station ranged between (35.5-99.2 mg/L). TSS values for the $2 \mathrm{nd}$ station were (40.2-140.8 $\mathrm{mg} / \mathrm{L}$ ). While TSS values for the third and fourth sampling stations ranged between (44.2 to $141.9 \mathrm{mg} / \mathrm{L}$ ). The current high TSS results shown in this study come in consistence with the ones obtained by (Alhassany \& Al-Bayyati, 2017; Matti, 2014). Though, the current study had much higher results than the previous studies.

Dissolved oxygen is a very important water characteristic. DO is necessary to preserve most forms of aquatic life and to allow the decomposition of organic matter, including organic wastes (Nesaratnam, 2014). The current study showed the average value of dissolved oxygen (DO) in the Tigris river water was ranging from $(6.8 \mathrm{mg} / \mathrm{L}$ to $6.8 \mathrm{mg} / \mathrm{L})$ at all the four sampled stations. These values are acceptable according to the Iraqi and international standards where DO values must not be less than $4 \mathrm{mg} / \mathrm{L}$. The current results agree with previous studies confirming that the dissolved oxygen levels in the Tigris River water are within the acceptable international standards (Matti, 2014; Al-Bayatti, Al-Arajy, and Al-Nuaemy, 2012).

Biochemical Oxygen Demand (BOD) is the amount of oxygen microorganisms use to decompose organic wastes that are present in water (Carmen, 2009). BOD is a very commonly used environmental test and considered as the most important marker of river water organic pollution (Nesaratnam, 2014). BOD values ranged between (3.5-5.9 mg/L) at sampling station 1 and $(5.5-6.9 \mathrm{mg} / \mathrm{L})$ at the second sampling station. While sampling station 3 and 4 registered BOD values ranging between $(5.5-6.9 \mathrm{mg} / \mathrm{L})$. The increased BOD range detected at the four sampling stations exceeds the international standards for BOD levels in river waters $(<5 \mathrm{mg} / \mathrm{L}$ ). The current results are much higher than the ones obtained by (AlZoubaidy, Sulaymon, \& Razzak, 2009; Ismail and Abed, 2013) indicating an increase in the BOD 
concentrations in the Tigris River water in Baghdad. High BOD concentrations in the Tigris River water indicate an increase in pollution caused by organic sources.

Chemical Oxygen Demand (COD) is the mass of oxygen needed for the complete oxidation of an organic compound present in water (Wiesmann, Choi, and Dombrowski, 2007). For this reason, COD is an important indicator of organic contamination in surface water. COD values for the 1 st sampling station ranged between (71.3-562.4 $\mathrm{mg} / \mathrm{L}$ ) while the 2 nd sampling station had values ranging from (70.8-620.5 $\mathrm{mg} / \mathrm{L})$. Sampling stations 3 and 4 had COD values ranging between $(70.1$ to $612.9 \mathrm{mg} / \mathrm{L})$. These results show the Tigris river water is heavily polluted with organic matter coming from the sewage discharged directly into the river without any treatment. Previous studies had similar results showing an increase in the COD values of the Tigris River water in Baghdad (Ma'alah, 2013; Alobaidy et al, 2010).

Nitrogen is present in the river water in the form of nitrate $\left(\mathrm{NO}_{3}\right)$. Presence of Nitrate in the water indicates that the river is polluted with sewage. Nitrate in river water can be a serious public health danger to both human and animal infants. High concentrations of nitrate in drinking water can even cause death (Drinan \& Spellman, 2001). Agricultural activities are considered the main source of nitrate pollution (Singh, \& Tripathi, 2007). Values of nitrate detected at the 1 st sampling station ranged from (3.6-11.3 $\mathrm{mg} / \mathrm{L})$ and (3.2-11.3 $\mathrm{mg} / \mathrm{L})$ for the $2 \mathrm{nd}$ sampling station. Sampling station $3 \mathrm{had}$ nitrate $\left(\mathrm{NO}_{3}\right)$ values ranging from (6.9-11.4 mg/L) and (8.7-11.9 mg/L) for sampling station 4. The high concentrations of nitrate in the four sampling locations are caused by the continuous wastes discharge, agricultural fertilizers, and domestic garbage dumps. Similar previous results obtained by (Al-Shemari \& Abdulhussain, 2013; Rabee, AbdulKareem, \& Al-Dhamin, 2011) indicated the presence of high nitrate levels in the Tigris River water in Baghdad. However, the current study showed higher nitrate $\left(\mathrm{NO}_{3}\right)$ values at the fourth sampling station. Previous studies did not register such higher values in that location. This shows that the sampling station 4 is being polluted heavily over the past few years.

There are two forms of sulfur (S) common in water and wastewater: sulfate $\left(\mathrm{SO}_{4}{ }^{2-}\right)$ and hydrogen sulfide $\left(\mathrm{H}^{2} \mathrm{~S}\right)$. Sulphate $\left(\mathrm{SO}_{4}{ }^{2-}\right)$ in high concentrations can cause a laxative effect and a bitter taste and is considered a nuisance in drinking water (Berthouex and Brown, 2018). The 1st sampling station had mean values ranging from $(130.5-420 \mathrm{mg} / \mathrm{L})$ and the $2 \mathrm{nd}$ sampling station had values ranged from (209.9-470.5 mg/L). Sampling station 3 had values ranged from (189.9-470.9 mg/L) and (188.3-470.8 $\mathrm{mg} / \mathrm{L}$ ) for the fourth sampling station. Previous studies (Hashim, 2018; Al-Fatlawy, Rabee \& AbdulKareem, 2011) showed similar high Sulphate concentrations indicating that the Tigris River water in Baghdad had increased levels of Sulphate and that those concentrations had exceeded the permissible international limits for Sulphate in freshwaters.

Phosphate $\left(\mathrm{PO}_{4}{ }^{3-}\right)$ is the ideal form of phosphorus $(\mathrm{P})$ for plant growth. It is a major cause of excessive algae growth and degraded water quality especially in lakes (Berthouex and Brown, 2018). Phosphate values at the four sampling stations ranged between $(0.8-0.99 \mathrm{mg} / \mathrm{L})$. The detected concentrations are within the acceptable WHO for phosphate in freshwaters. 


\section{Conclusion:}

Surface river water of the Tigris River seems to deteriorate starting from the north of Baghdad to the south of Iraq. The results of the current study concluded that the Tigris River water at the four sampling stations characterized with high level of TDS, TSS, $\mathrm{TH}$, turbidity, $\mathrm{BOD}, \mathrm{COD}, \mathrm{NO}_{3}$, and $\mathrm{SO}_{4}{ }^{2-}$. Mean values of these parameters exceeded the WHO limits in river waters. The current research confirmed previous studies, which had similar results showing the increase of pollution in the Tigris River water. Sources of the Tigris River water pollution mainly come from the continuous industrial influents that are discharged into the river without prior treatment. This will lead to the deterioration of the Tigris River water quality and increased levels of pollution with different chemicals. The current study indicated that the primary source of the Tigris River water pollution comes from sewage effluents that are directly discharged into the river water without proper treatment. Previous studies (Al-Ansari, Ali \& Knutsson, 2015; Hamza, 2007) showed the current waste management methods applied in Iraq need further investigation and review to better handle the increasing pollution levels coming from the sewage. The consequences of such pollution would include the Tigris River water quality impairment, drop in fish abundance, and will have a severe effect on water usage for recreation (swimming, wading, and boating), industrial, and domestic purposes. The increased municipal and agricultural wastes that are directly discharged into the Tigris River water without proper treatment remain a major environmental challenge and a public health threat to the Tigris River water. In general, the Tigris River water quality is poor and this result is consistent with the findings of previous studies confirming the deterioration of the Tigris River water quality in Iraq (Ewaid, Abed, \& Kadhum, 2018; Al-Musawi \& Al-Rubaie, 2017; Al-Sabah, 2016; Al-Murib, 2014).

\section{Recommendations:}

Immediate measures are required to be taken to end the nonstop inflow of sewage and wastes into the Tigris River water from the residential, commercial, and institutional activities in Baghdad. It's very important to call for speeding up drafting local environmental legislations and laws in Iraq as soon as possible. Rehabilitating and renovating waste management methods adopted by the local authorities is a key step towards improving water quality in Iraq. Moreover, further detailed studies covering more sampling stations along the Tigris River in Iraq should be conducted so that we can better compare results. Finally, a nation-wide media campaign would be necessary to help educate officials and citizens about the public health, environmental, and economic dangers of the Tigris River pollution in Iraq.

\section{Declarations}

\section{Acknowledgements:}

This research received no specific grant from any funding agency in the public, commercial, or not-forprofit sectors. 


\section{Conflict of Interest:}

"The authors declare that there are no conflicts of interest regarding the publication of this manuscript".

\section{References}

1. Adams VD (2017) Water and wastewater examination manual. Routledge.

2. Al-Abdrabba WM, Mohammed ZB, Hazaa MM, and Resheq AS (2015) Evaluation of the Tigris River Water Quality for Domestic and Irrigation Uses Near Drinking Water Treatment Plants through Baghdad City. International Journal of Management and Applied Science (IJMAS), pp. 63-68, Volume-1, Issue-9

3. Al-Ansari N, Ali AA, \& Knutsson S (2015) Iraq Water Resources Planning: Perspectives and Prognoses.

4. Al-Ani, R. R., Al Obaidy, A. M. J., \& Hassan, F. M. (2019). Multivariate Analysis for Evaluation the Water Quality of Tigris River Within Baghdad City in Iraq. The Iraqi Journal of Agricultural Science, 50(1), $331-342$.

5. Al-Bayatti KK, Al-Arajy KH, and Al-Nuaemy SH (2012) Bacteriological and physicochemical studies on Tigris River near the water purification stations within Baghdad Province. Journal of environmental and public health. https://doi.org/10.1155/2012/695253.

6. Abd Al-Kareem AF, Al-Arajy KH, and Jassim KA (2015) Microbiological Analysis on Tigris River Water in the Selected Sites in Baghdad Province, Iraq. Journal of Environment and Earth Science 5:60-64.

7. Al-Fatlawy YF, Rabee AM, \& Abdul-Kareem BM (2011) Monitoring heavy metals, cations and anions levels and its possible health risks in Tigris River at Baghdad region. Iraqi Journal of Science, 52(3), 306-316.

8. Al-hassany JS\& Al- Bayyati HE (2017) Screening of Epiphytic Algae on the Aquatic Plant Phragmites australis inhabiting Tigris River in Al-Jadria Site, Baghdad, Iraq. Baghdad science journal 14(1): 8598.

9. Al-Hiyali, Ma'alah, and Al-Azzawi, (2016) Evaluating the Effects of Medical City Wastewater on Water Quality of Tigris River. Eng. \& Tech. Journal 3:405-417.

10. Ali SK (2018) Assessment of the Tigris River Water Quality in Selected Iraqi Governments. IJSR (7) 1:500-504.

11. Ali SM and Shaban HS (2014) Characterizing of some hydrochemical parameters of Tigris river, Iraq with the aid of GIS. Journal of natural science research 22:6-18.

12. Al-Marsoumi AH, Al-Bayati KM, Al-Mallah EA (2006) Hydrogeochemical aspects of Tigris and Euphrates Rivers within Iraq: A comparative study. Raf. Jour. Sci 17:34-49. 
13. Al-Murib M (2014) Application of CE-QUAL-W2 on Tigris River in Iraq. MSc thesis. Portland state University.

14. Al-Musawi, N. O., \& Al-Rubaie, F. M. (2017). Prediction and Assessment Of Water Quality Index Using Neural Network Model And GIS Case Study: Tigris River In Baghdad City. Applied research journal (3) 11: 343-353.

15. Al-Obaidi AH (2009) Evaluation of Tigris River Quality in Baghdad for the period between (November 2005- October2006). Eng. \& Tech. Journal 27: 1736-1745.

16. Al-Obaidy AM, Al-Janabi ZZ, and Al-Mashhady AA (2016) Distribution of Some Heavy Metals in Sediments and Water in Tigris River. Journal of Global Ecology and Environment 3: 140-146.

17. Al-Obaidy AH, Al-Janabi ZZ, \& Shakir E (2015) Assessment of water quality of Tigris River within Baghdad City. Mesop. Environ. j, 1(3), 90-98.

18. Al-Obaidy AM, Al-Janabi ZZ, and Al-Kubaisi AA (2014) Distribution of Some Heavy Metals in Tigris River middle of Iraq. Baghdad science journal 11:983-990.

19. Alobaidy AH, Al-Sameraiy MA, Kadhem JA, \& Majeed AA (2010). Evaluation of treated municipal wastewater quality for irrigation. Journal of Environmental Protection, 1(03), 216.

20. Al-Quraishi, A. M. F., \& Negm, A. M. (2019). Environmental Remote Sensing and GIS in Iraq. SpringerWater, Springer-Water, Springer, Cham.

21. Al-Sabah BJ (2016) Application of Water Quality Index to Assessment of Tigris River. Int.J.Curr.Microbiol.App.Sci 5(10): 397-407.

22. Al-Saady, Y. I., \& Abdullah, E. J. (2014). Water Quality of Tigris River within Missan Governorate eastern part of the Mesopotamia Plain-Iraq. Journal of University of Babylon, 22(9), 2502-2489.

23. Al-Shemari HM \& Abdulhussain IA (2013). Study the effect of Baghdad City on the Tigris River water pollution. Basrah Journal for Engineering Science, 13(1), 140-156.

24. Alwan HH, Muhammed JM, Jassem HJ (2013) Physical assessment of the Tigris River raw water in the city of Baghdad. Journal of Babylon University/Engineering Sciences 21:1116-1125.

25. Al-Shujairi SO, Sulaiman So, and Najemaldin MA (2015) Variations of major ionic composition and salinity of Tigris river within Baghdad. Sulaimani journal for engineering science 2:64-70.

26. Al-Suhili RH, Khudair BH, and Abdulrazzak AM (2016) Prediction of Raw Water Turbidity at the Intakes of the Water Treatment Plants along Tigris River in Baghdad, Iraq using Frequency Analysis. Journal of Engineering 22: 22-35.

27. Al-Zoubaidy AJ, Sulaymon AH, \& Razzak IA (2009). Modeling the distribution of (BOD) and (TDS) in part of Tigris River within Baghdad. Journal of Engineering, 15(2), 3673-3690.

28. American Public Health Association (2017) Standard Methods for the Examination of Water and Wastewater, Volume 4. CHIZINE PUBN, Ontario.

29. Atta, H. A. (2020). Assessment and geographic visualization of salinity of Tigris and Diyala Rivers in Baghdad City. Environmental Technology \& Innovation, 17, 100538. 
30. Balasim HM (2013) Assessment of some heavy metals' pollution in water, sediments and Barbus xanthopterus (Heckel, 1843) in Tigris River at Baghdad city (Doctoral dissertation, College of Science, University of Baghdad, 159pp).

31. Basílico G, de Cabo L, and Faggi A (2015) Phytoremediation of water and wastewater: on-site and full-scale applications. In: Ansari AA et al (ed) Phytoremediation-management of environmental contaminants Volume 2, 1st edn. Springer; Cham, pp 51-60.

32. Berthouex PM and Brown LC (2018) Chemical processes for pollution prevention and control. CRC Press.

33. Boyd CE (2015) Water quality: An introduction. 2nd ed. Springer.

34. Carmen W (2009) A comprehensive dictionary of inorganic chemistry. Abhishek Publications.

35. Chapman D (2003) Water Quality Assessments: A guide to the use of biota, sediments and water in environmental monitoring. E\&FN Spon, London.

36. Dabdoob MA, Ibrahim SA (2012) Using Three Statistical Analyses for Studying the Total Water Hardness of Tigris River in Mosul Town. Iraqi Journal for Statistical Sciences 22: 66-81.

37. Drinan JE, Spellman FR (2001) Water and Wastewater Treatment: A Guide for the Non-engineering Professional. CRC Press.

38. Ewaid SH, Abed SA, \& Kadhum SA (2018). Prediction the Tigris River water quality within Baghdad, Iraq by using water quality index and regression analysis. Environmental Technology \& Innovation.

39. Flayyh HA, Rasheed KA (2016) Study of some physico-chemical characteristics of the Tigris River in the city of Baghdad. Assyot Univ. Bull. Environ. Res 19:31-42.

40. Hamza JN (2008) Impact of Tigris River Pollution on the Performance of Water Treatment Plants Efficiencies in Baghdad City. Iraqi Journal of Chemical and Petroleum Engineering 9: 17-24.

41. Hashim AG (2018) The physico-chemical properties of southern part of Diyala River water. Iraqi Journal of Science 58: 2322-2331.

42. Ibrahim MA, Abd Ali ZT, Hussein HA (2018) Application of Cluster Analysis and Multivariate Statistical Techniques Associated with Water Quality Index to Evaluate Water Quality of Tigris River in Iraq. Journal of engineering sciences 1: 21-35. Available from: https://www.jaaru.org/index.php/auisseng/article/view/76

43. Ishnawa HT, Fari JA, Sadeq ZQ (2009) A study on the environmental situation of the Medical City Compound in Baghdad. Ministry of Environment, Dept. of Monitoring and Evaluation of industrial activities. (In Arabic).

44. Ismail AH, Abed AG (2013) BOD and DO modeling for Tigris River at Baghdad city portion using QUAL2K model. Journal of Kerbala University (11)3:257-273.

45. Matti, LY (2014) Seasonal variations of raw water of Tigris River and effect on quality water plants. Journal of University of Duhok: Pure and Engineering Sciences 1(17), 55-71.

46. Ma'alah WN (2013) Examining the effects of Baghdad medical city waste water on the quality of Tigris River. MSc thesis. University of Baghdad. 
47. Mensoor M, Said A (2018) Determination of Heavy Metals in Freshwater Fishes of the Tigris River in Baghdad. Fishes 3(2):23. https://doi.org/10.3390/fishes3020023

48. Mustafa SA (2012) Investigation of copper and zinc in phytoplankton in section of Tigris River at Baghdad City. M.Sc. Thesis. College of Science, University of Baghdad.

49. Nesaratnam ST (2014) Water pollution control. John Wiley \& Sons Ltd.

50. Okorafor KA, Agbo BE, Johnson AM, Chiorlu M (2012) Physico-chemical and bacteriological characteristics of selected streams and boreholes in Akamkpa and Calabar Municipality, Nigeria. Archives of Applied Science Research, 4 (5):2115-2121.

51. Rabee AM, Abdul-Kareem BM, \& Al-Dhamin AS (2011). Seasonal variations of some ecological parameters in Tigris River water at Baghdad Region, Iraq. Journal of Water Resource and Protection, 3(04), 262.

52. Rahi KA \& Halihan T (2018) Salinity evolution of the Tigris River. Reg Environ Change. https://doi.org/10.1007/s10113-018-1344-4.

53. Rice, A., Baird, E. W., \& Eaton, R. B. (2017) APHA 2017 Standard Methods for Examination of Water and Wastewater (Washington: American Public Health Association, American Water Works Association, Water Environment Federation ISBN).

54. Singh, S. N., \& Tripathi, R. D. (Eds.). (2007). Environmental bioremediation technologies. Springer Science \& Business Media.

55. Spellman FR (2003) Handbook of water \& wastewater treatment plant operations. CRC Press.

56. Tolgyessy J (1993) Chemistry and biology of water, air, and soil: environmental aspects. Elsevier.

57. Wiesmann U, Choi IS, and Dombrowski E (2007) Fundamentals of biological wastewater management. Wiley.

58. World Health Organization (2017). Guidelines for drinking-water quality: Incorporating first addendum.

59. World Health Organization (2002) Drinking Water Guidelines; Bacteriological Parameters. World Health Organization, Geneva 5, 2.

\section{Figures}


Fig. 1: seasonal variations of physicochemical characteristics at station 1

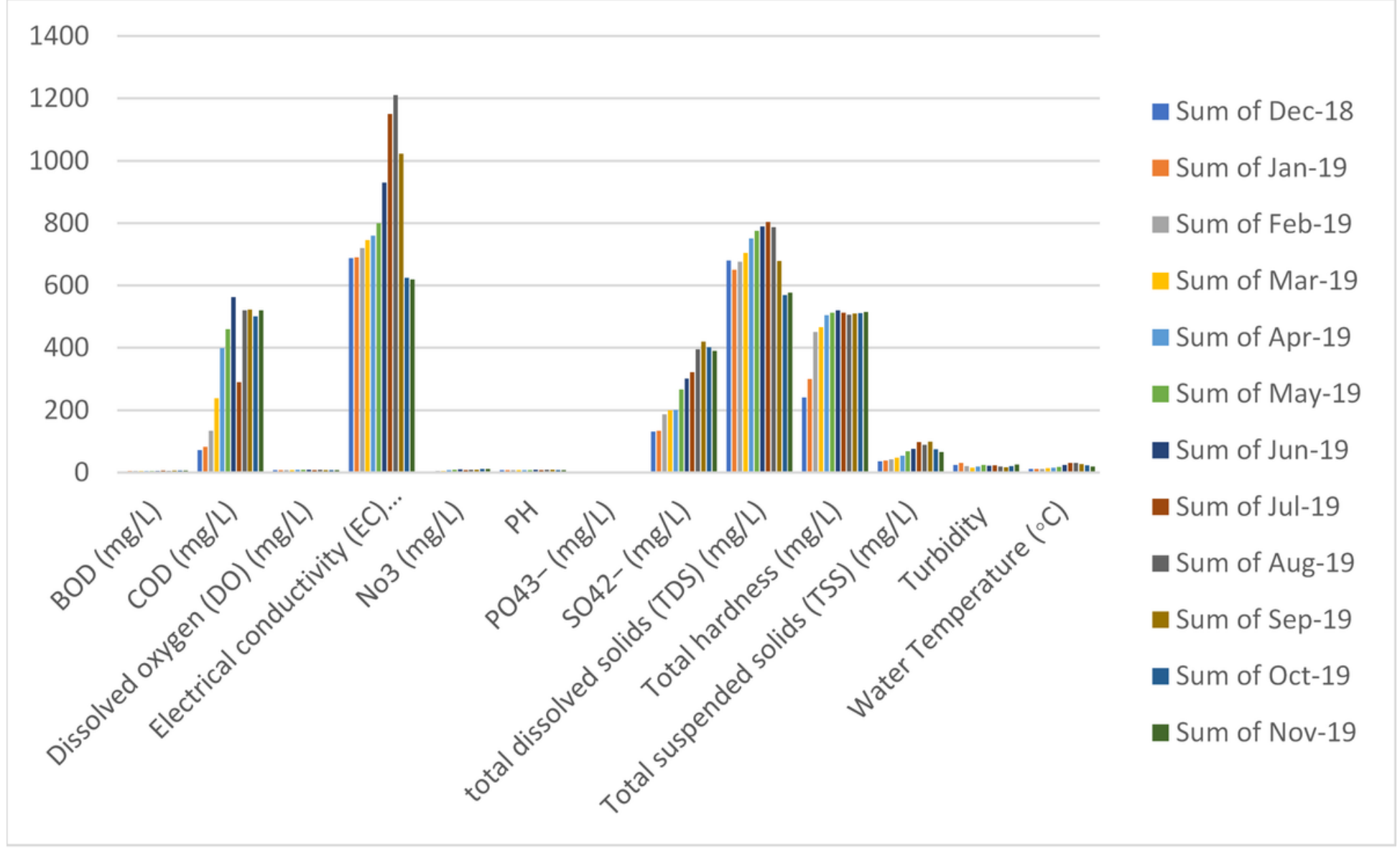

Figure 1

seasonal variations of physicochemical characteristics at station 1 
Fig. 2: seasonal variations of physicochemical characteristics at station 2

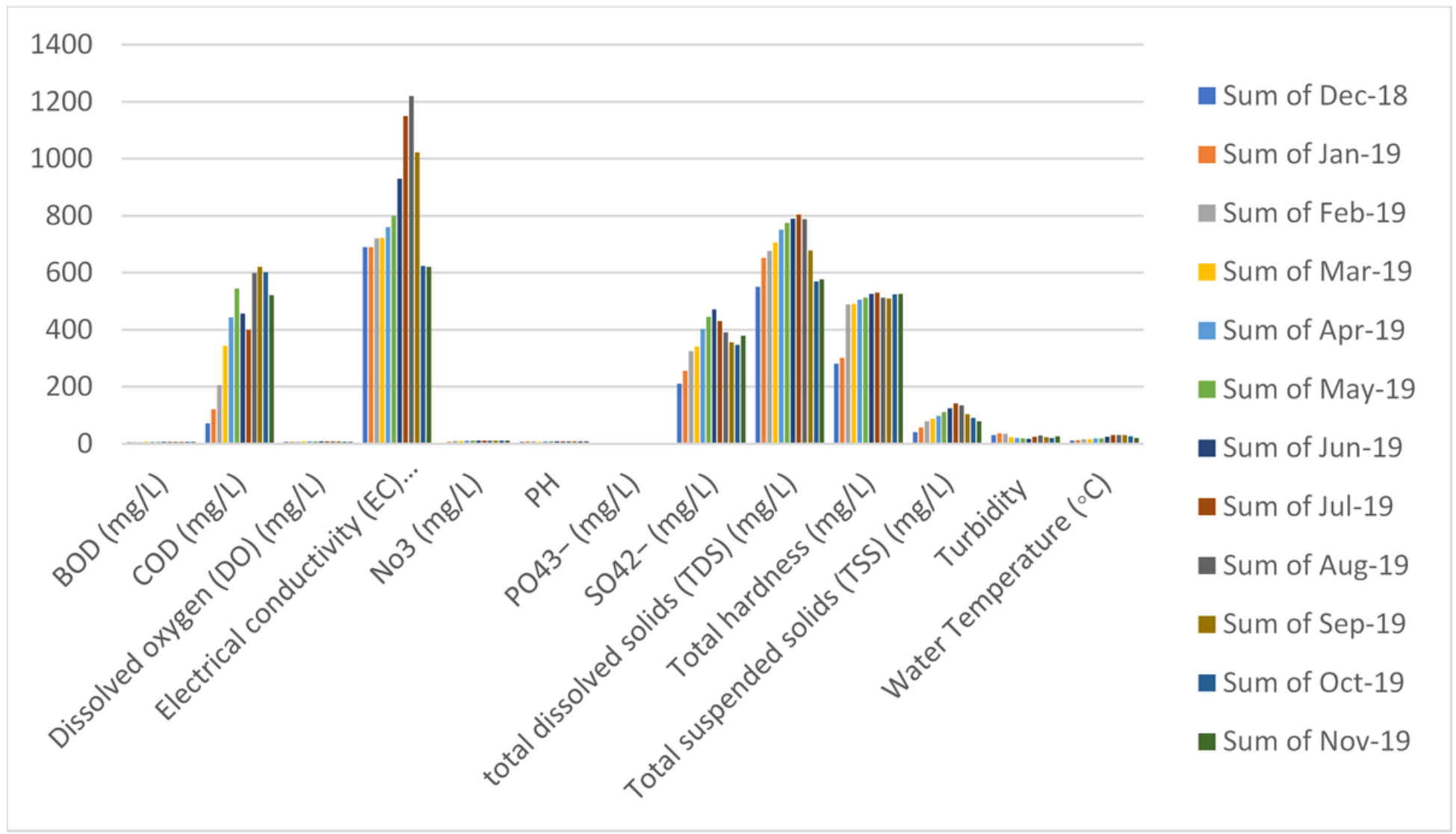

Figure 2

seasonal variations of physicochemical characteristics at station 2 
Fig. 3: seasonal variations of physicochemical characteristics at station 3

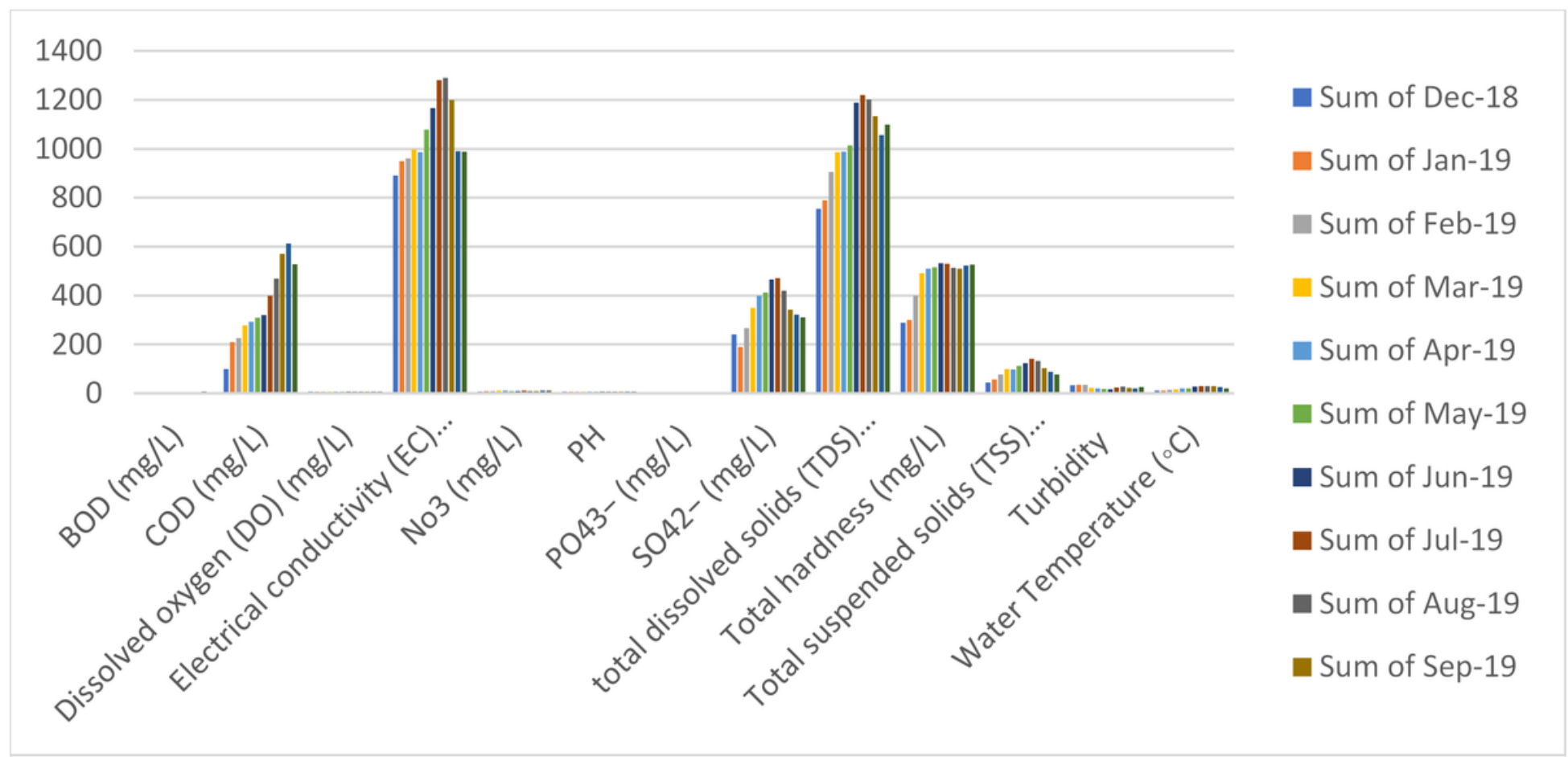

Figure 3

seasonal variations of physicochemical characteristics at station 3 
Fig. 4: seasonal variations of physicochemical characteristics at station 4

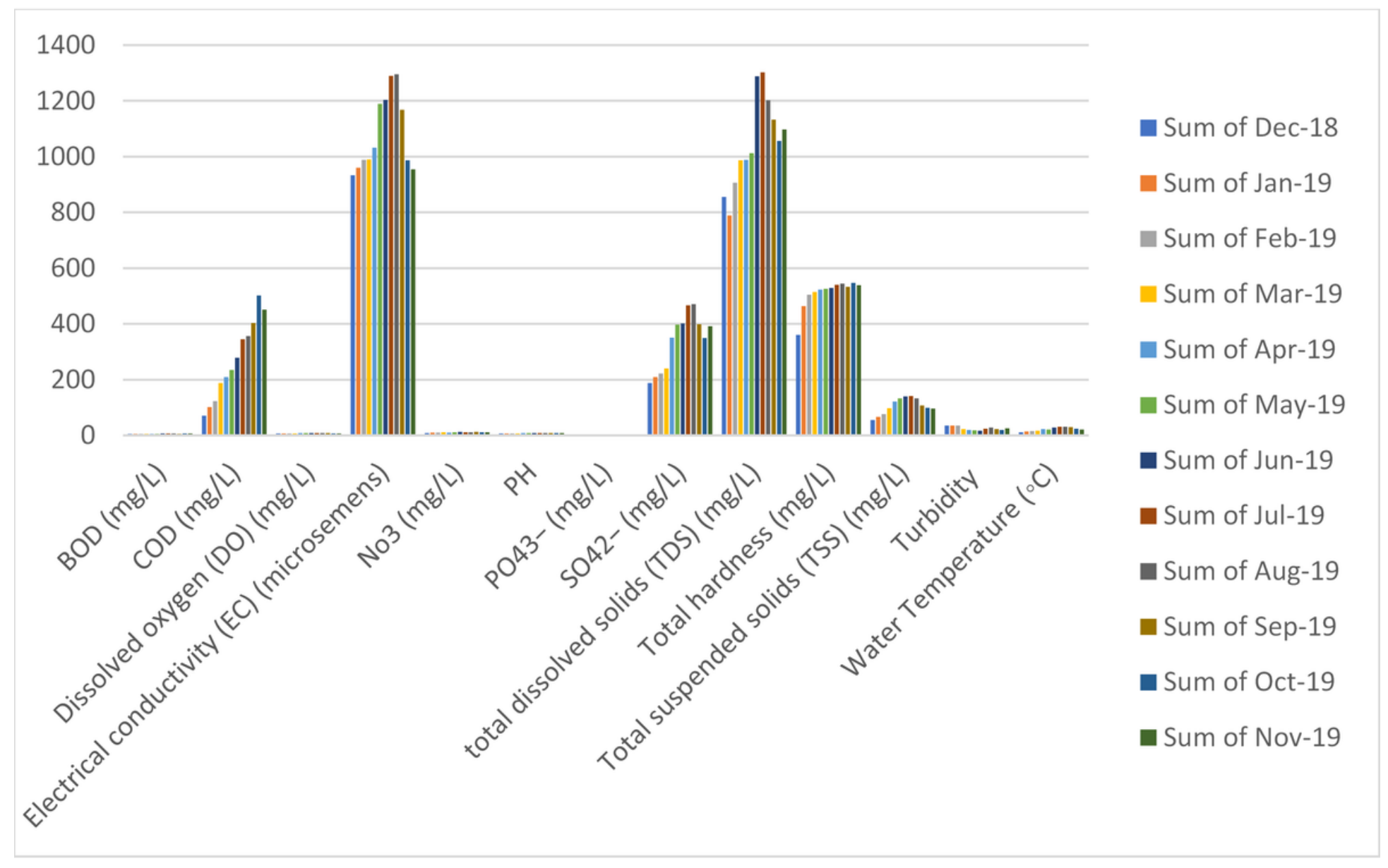

Figure 4

seasonal variations of physicochemical characteristics at station 4 